\title{
Climate change effects on emperor penguins
}

\section{Efectos del cambio climático en los pingüinos emperador}

\author{
Taibah Alhatem ${ }^{l}$, Casilda Saavedra ${ }^{2 *}$ \\ ${ }^{1}$ Wilkes University, ${ }^{2}$ Universidad Tecnológica de Panamá
}

\begin{abstract}
Climate change is one of the major issues affecting our mother Earth. The change in climate include both the change in temperature and the change in precipitation. Both of these parameters are very crucial to animals and plants where they depend on them for their survival. Climate change has so many negative impacts on the biodiversity of the Earth especially in the Arctic and Antarctic continents. The rise in temperature decreases the ice coverage which in return reduces the population of the wildlife. The ice coverage is crucial to the biodiversity living in Antarctica where they depend on it for their survival. It's very important for their feeding, breeding, and habitat. However, with the reduction of ice, many animals are becoming close to extinction. One of those species that were negatively impacted by climate change is emperor penguins (Aptenodytes forsteri). These penguins require very low temperatures in order to breed and populate. Very high temperatures for these penguins could result in decreased population rate around Antarctica. An analysis was done of emperor penguin population data found in different research papers in conjunction with temperature anomalies data in Antarctica from 1983 to 2005 from the National Oceanic and Atmospheric Administration (NOAA). The results indicated that there was an inverse relationship between the temperature and the penguin's population. It was shown through the analysis conducted that the temperature impacted the penguins negatively throughout the years since the temperature was rising. It decreased their breeding population and chicks count dramatically in all the parts of Antarctica tested.
\end{abstract}

Keywords Climate Change, Temperature, Population, Emperor Penguin.

Resumen El cambio climático es uno de los principales problemas que afectan a nuestra madre Tierra. El cambio en el clima incluye tanto el cambio en la temperatura como el cambio en la precipitación. Ambos parámetros son muy importantes para los animales y las plantas, ya que dependen de estos para su supervivencia. El cambio climático tiene muchos impactos negativos en la biodiversidad de la Tierra, especialmente en los continentes ártico y antártico. El aumento de la temperatura disminuye la cobertura de hielo, lo que a su vez reduce la población de la vida silvestre. La cobertura de hielo es crucial para la biodiversidad que vive en la Antártida. Esta es muy importante para su alimentación, reproducción y hábitat. Sin embargo, con la reducción del hielo, muchos animales se están acercando a la extinción. Una de esas especies que han sido afectadas negativamente por el cambio climático son los pingüinos emperador (Aptenodytes forsteri). Estos pingüinos requieren temperaturas muy bajas para reproducirse y poblarse. Las temperaturas muy altas para estos pingüinos podrían resultar en una disminución de la tasa de población alrededor de la Antártida. Se realizó un análisis de los datos de la población de pingüinos emperador encontrados en diferentes trabajos de investigación junto con datos de anomalías de temperatura en la Antártida desde 1983 hasta 2005 de la Administración Nacional Oceánica y Atmosférica (NOAA). Los resultados indicaron que existe una relación inversa entre la temperatura y la población de pingüinos emperador. Se mostró a través del análisis realizado que la temperatura impactó negativamente a los pingüinos a lo largo de los años. Se evidenció una disminución de su población reproductora y una dramática disminución de los polluelos en todas las regiones estudiadas de la Antártida.

Palabras clave Cambio climático, temperatura, población, pingüino emperador.

* Corresponding Author: casilda.saavedra@utp.ac.pa

\section{Introduction}

The world is suffering from different issues that keep negatively impacting our mother Earth. One of these major problems is Climate Change. Climate Change is known as "a change in the state of the climate that can be identified by changes in the mean and/or the variability of its properties, and that persists for an extended period, typically decades or longer" [1]. These changes include the change in the annual rainfall average or the change in the average temperature [2]. There are multiple different effects of climate change including rise in temperature, longer frost-free season, precipitation patterns change, droughts and heat waves, stronger storms and hurricanes, the rise in sea level, global warming and reduction in the ice coverage in the Artic and Antarctica [3]. All these reasons will disturb the pattern and circle of life of the environment around us, having long term effects and impacts on the living creatures roaming the Earth including us humans. 
One of these impacts of climate change was the declining rates of wildlife and plants, especially the Arctic and Antarctic biodiversity. The impact of climate change can lead to the extinction of some the species living in the Arctic and Antarctic due to the fact that they are more sensitive to temperature changes than other creatures.

Emperor penguin (Aptenodytes forsteri) is one of those species that are negatively affected by climate change. They are the largest penguin species known where they can weight up to $40 \mathrm{~kg}$ by adulthood. Emperor Penguins are abundant and scattered around the Antarctic continent in the southern hemisphere, having the ability to endure very low temperatures below zero due to their thick feather coat and their small bills and flippers that conserve heat. They are also able to reserve energy due to their body fat. This specific specie usually breeds during the winter season in Antarctica where they require a temperature as low as -40Co [4]. However, due to climate change and the rise in temperature, their breeding has been disturbed as well as their food source which caused their population rate to declining throughout the years [5][6].

A collection of studies was analyzed in which different colonies within Antarctica were tested for the abundance of these penguins. The colonies tested include Cape Crozier, Beaufort Island, Franklin Island, Cape Washington, Coulman Island, and Cape Roget. According to the authors of these studies, aerial photos were taken by a winged aircraft from both the sky and the ground to determine the number and the abundance of live penguin chicks at these colonies. Each colony was observed and counted for the live chicks and then the mean was taken during the ground counts. After maintaining the chick's numbers, the months averages were taken. The relationship between the breeding population and the climate variables was also determined using Pearson's coefficient $r$ [7].

Using data obtained from research studies of emperor penguin populations in the Antarctic for the period 1983 to 2005, and temperature data from the National Oceanic and Atmospheric Administration (NOAA), a statistical analysis was conducted to determine the effect of climate change on emperor penguins. The objective of this analysis was to determine how the climate change is affecting the breeding population of these penguin species.

\section{Hypothesis}

The rise in temperature due to climate change is negatively impacting the emperor penguins breeding and therefore decreasing their population.

\section{Methodology}

A statistical analysis was conducted on the breeding population data of emperor penguins and compared to the temperature anomalies during that a specific period of time. The time period chosen was between 1983 and 2005 due to the lack of new reports containing updated data. The data found included the counts of chicks or the breeding population of emperor penguins born between 1983 and 2005 at six different locations around Antarctica. The locations include Cape Crozier, Beaufort Island, Franklin Island, Cape Washington, Coulman Island, and Cape Roget. However, some of the data was missing for some of the locations which limited the analysis for some of the years.

The temperature anomaly for that specific period of time was also found using a temperature anomaly graph and table that specified the temperatures variability in Antarctica from 1983 to 2005. Temperature anomaly is defined as "a departure from a reference value or long-term average" [8]. The temperature anomaly values were all positive numbers which indicate that the temperature at that time period was warmer than usual. If there were negative numbers, it would have indicated that the temperature in Antarctica was cooler than usual [8]. The temperature anomaly data was obtained from the National Oceanic and Atmospheric Administration (NOAA).

After obtaining all the required data, it was organized and tabulated accordingly. Table 1 summarized the temperature anomaly in Celsius against the time period in years. Whereas table 2 summarized Antarctica's penguins' colonies along with the number of live chicks found at the different locations.

\section{Results}

Table 1. The change in temperature over time in years in Antarctica

\begin{tabular}{|c|c|}
\hline Year & Anomaly $\left(\mathrm{C}^{\circ}\right)$ \\
\hline 1983 & 0.56 \\
\hline 1986 & 0.40 \\
\hline 1989 & 0.30 \\
\hline 1990 & 0.49 \\
\hline 1992 & 0.47 \\
\hline 1993 & 0.47 \\
\hline 1994 & 0.46 \\
\hline 1995 & 0.55 \\
\hline 1996 & 0.47 \\
\hline 1997 & 0.62 \\
\hline 1998 & 0.85 \\
\hline 1999 & 0.53 \\
\hline 2000 & 0.40 \\
\hline 2001 & 0.52 \\
\hline 2002 & 0.77 \\
\hline 2003 & 0.80 \\
\hline 2004 & 0.71 \\
\hline 2005 & 0.94 \\
\hline & \\
\hline
\end{tabular}

*The data from [9]

Table 2. The breeding population of chicks around Antarctica colonies

\begin{tabular}{cccccc|}
$\begin{array}{ccc}\text { Cape } \\
\text { Crozier }\end{array}$ & $\begin{array}{c}\text { Beaufort } \\
\text { Island }\end{array}$ & $\begin{array}{c}\text { Franklin } \\
\text { Island }\end{array}$ & $\begin{array}{c}\text { Cape } \\
\text { Washington }\end{array}$ & $\begin{array}{c}\text { Coulman } \\
\text { Island }\end{array}$ & $\begin{array}{c}\text { Cape } \\
\text { Roget }\end{array}$ \\
\hline \multicolumn{4}{c}{ Breeding Population (Chicks Counts) } \\
\end{tabular}


Alhatem (et al): Climate change effects on emperor penguins

\begin{tabular}{|c|c|c|c|c|c|}
\hline 78 & 175 & 4,893 & 16,384 & 21,708 & 3,777 \\
\hline--- & --- & --- & 19,364 & --- & --- \\
\hline--- & --- & --- & 22,819 & --- & --- \\
\hline 324 & ---- & --- & 23,502 & 27,920 & 6,921 \\
\hline 374 & --- & --- & 26,511 & 34,735 & 6,478 \\
\hline--- & --- & --- & 23,920 & 18,767 & 6,551 \\
\hline 645 & 1,356 & 1,548 & 23,780 & 20,204 & 6,358 \\
\hline 623 & 412 & 1,785 & 22,354 & --- & --- \\
\hline 859 & 1,360 & 3,241 & 17,896 & 19,471 & 7,207 \\
\hline 821 & --- & --- & --- & --- & --- \\
\hline 1,108 & --- & --- & --- & --- & --- \\
\hline 798 & --- & --- & --- & --- & --- \\
\hline 1,201 & 2,038 & 2,915 & 17,397 & --- & --- \\
\hline 0 & 1,065 & 1,496 & 18,734 & --- & --- \\
\hline 247 & 1,430 & --- & 11,093 & --- & --- \\
\hline $333 *$ & 364 & 2,598 & 13,163 & --- & --- \\
\hline 475 & 131 & 5,145 & 16,700 & --- & --- \\
\hline 0 & 628 & 1,966 & 23,021 & 24,207 & --- \\
\hline *The number was assumed based on the number of adults available. Datra from [7] & \\
\hline
\end{tabular}

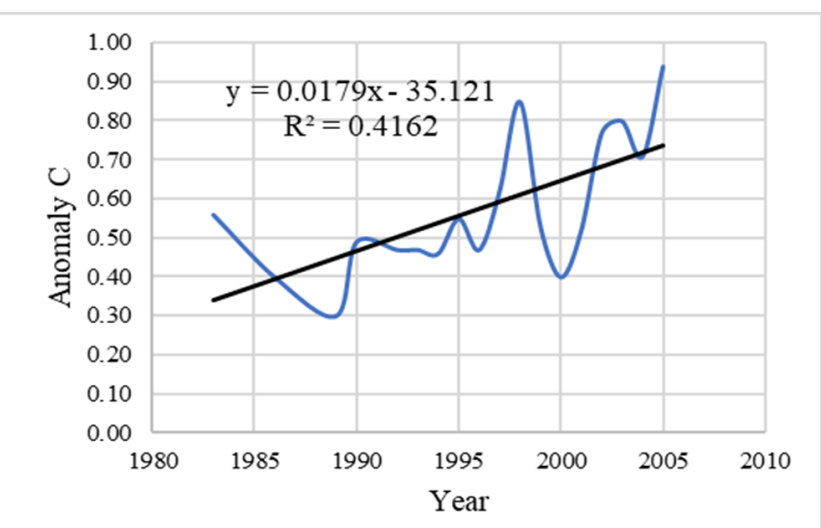

Figura 1.The change in temperature anomaly over time in years.

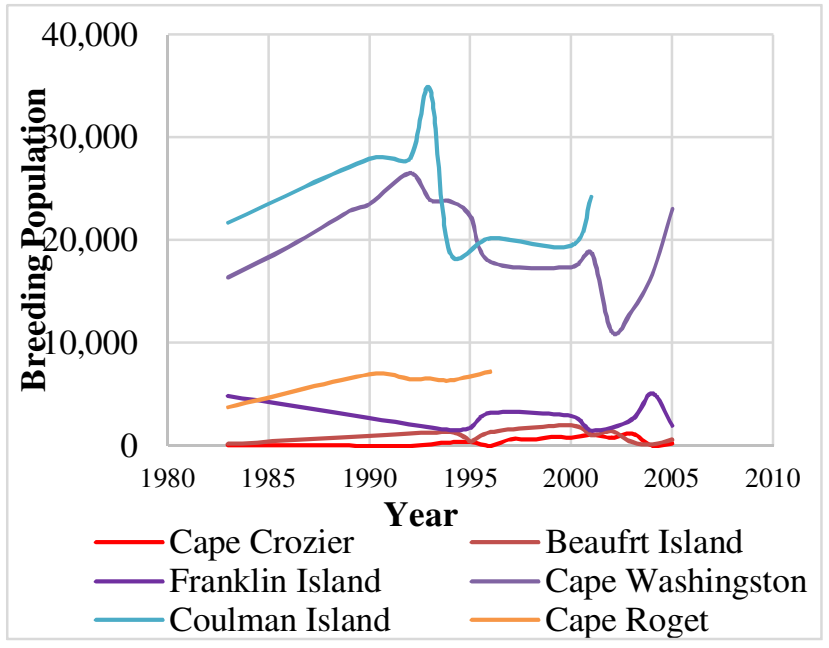

Figura 2.The relationship between the breeding population over time in years.

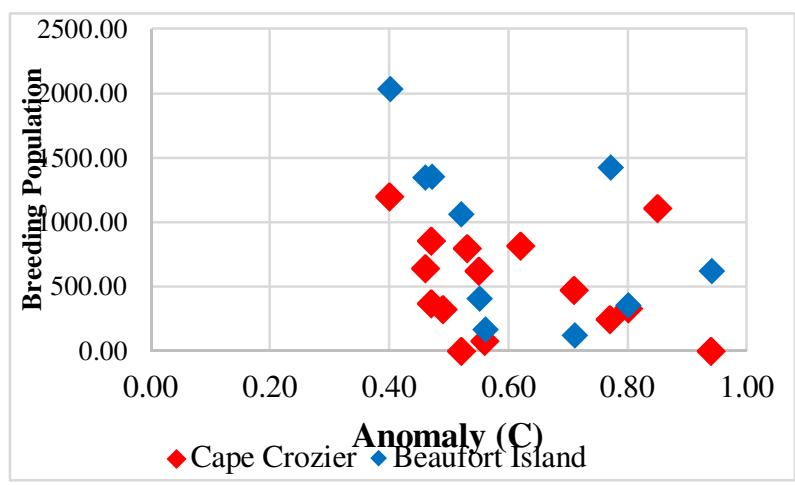

Figura 3. The relationship between the temperature and the breeding population in the specified locations.

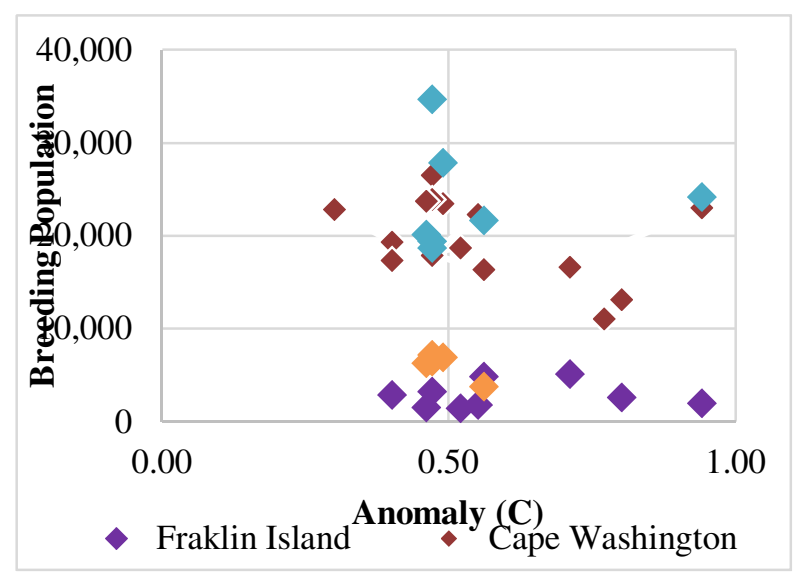

Figura 4. The relationship between the temperature and the breeding population in the specified locations.

\section{Discussion}

The relationships among the variables such as the population rate of the emperor penguins throughout a period of 18 years (between 1983 and 2005) were analyzed. The relationship between the rate of population and temperature anomaly as well as the change in temperature anomaly throughout the years was determined using a statistical analysis. The different colonies in Antarctica had different breeding populations as well, taking into consideration that some of the chicks counts data was missing (see table 2). The different colonies included Cape Crozier, Beaufort Island, Franklin Island, Cape Washington, Coulman Island, and Cape Roget.

Over time, the temperature in Antarctica started increasing gradually. These warm temperatures had a negative impact on Antarctica's wildlife, especially the emperor penguins. The relationship between the penguin's population and temperature anomaly show that the higher the temperature anomaly, the fewer penguins were born (see figure 2). For instance, Coulman island had the highest rate of the population at 0.47 Co. However, by 2005 , the population rate declined dramatically with an increase in temperature reaching $0.94 \mathrm{Co}$. 
The same case goes for all locations where the population rate decreased with the increase in temperature. Therefore, there was an inverse relationship between the breeding and temperature (see figure 2). When the temperature increases, the penguin's population decrease.

The relationship between temperature anomaly over the time period in years indicated that the temperature did not have a constant trend over time (see figure 1). The anomaly increased and decreased over time throughout the years having values that were higher than the trend line and others that were lower. The anomaly had a range between 0.30 Co to $0.94 \mathrm{Co}$ which are considered high temperature anomaly rates for emperor penguins. The lowest anomaly found was very warm for the biodiversity living in Antarctica including the emperor penguins. This type of birds usually breeds in temperatures as low as $-40 \mathrm{oC}$. However, the anomalies found during that time had much warmer temperatures. Having these high temperatures declined the population rate where it decreased the chances of breeding.

The relationship between the breeding population over time in years was also determined. The relationship indicated that there were differences between the locations throughout the years. Coulman island had the highest population rate in comparison with the other locations (see figure 4). Whereas Cape Crozier had the lowest breeding population over time where it had 0 chicks by 2005 (see Figure 3). The breeding population differed in all locations over time, meaning it increases and decreased as the years passed. Some of the data, however, was missing for some locations in specific years which can also affect the research. To conclude from all of the locations tested, the population rate dramatically decreased for all the locations except for Beaufort island (see figure 3). For instance, Coulman island had the highest population rate in 1992. However, in 1993, there was a dramatic drop in the emperor penguin's population rate (see Figure 4). The same case goes for Cape Washington, where the highest number of penguins were born in 1992 and then the rate started dropping from 1993 until 2005 (see Figure 4). Cape Roget had less data than the other locations, but from what is visible, the population was increasing. Beaufort island was the only location that had an increasing population until 2005 (see figure 3).

\section{Conclusions}

Climate change is known as the weather changes occurring in a region. Climate change affects all sorts of biodiversity on Earth including animals and plants. One of those species was the emperor penguin which require very low temperature to survive. However, with the change in climate and the increase in temperature in Antarctica, the population rate was declining since these penguins require very low temperatures to breed as well as a good food source. The fact that the rate of breeding was decreasing proved the hypothesis made where the temperature increases, the penguins population decreases.
Generally, climate change negatively impacts the wildlife and plants by declining their population and destroying their habitat which eventually leads them to extinction. These impacts will affect us as well in the near future if there was no action taken neither a solution found. It can decrease our food sources, clean air, and can cause more solid waste in the environment making it inhabitable.

There are different solutions that can be taken into consideration in order to reduce climate change. Some of these solutions include the reduction of oil, coal, fuel fuels, and natural gas usage, reducing vehicles numbers by using public transportation and bikes or moving closer to work. The upgrade of infrastructure where building some energy efficient buildings to reduce green-house gas emissions.

\section{ACKNOWLEDGMENT}

I would like to thank the $100-\mathrm{K}$ Strong in the Americas Grant, Wilkes University and Universidad Tecnológica de Panamá for giving me the opportunity to do an exchange program at UTP. Thank you to Dr. Casilda for the help through the construction of this research as well as the information which were very beneficial throughout the process of writing this report.

\section{REFERENCES}

[1] C. Change, "What Climate Change," 2016.

[2] J. Gregory, T. Stocker, P. Lemke, and N. Bindoff, "Climate change 2007: the physical science basis," Contrib., 2007.

[3] T. R. Karl and K. E. Trenberth, "Modern global climate change," Science (80-. )., vol. 302, no. 5651, pp. 1719-1723, 2003.

[4] D. J. Mccafferty, C. Gilbert, A.-M. Thierry, J. Currie, Y. Le Maho, and A. Ancel, "Emperor penguin body surfaces cool below air temperature," Biol. Lett., vol. 9, no. 3, p. 20121192 , 2013.

[5] B. Wienecke, G. Robertson, R. Kirkwood, and K. Lawton, "Extreme dives by free-ranging emperor penguins," Polar Biol., vol. 30, no. 2, pp. 133-142, 2007.

[6] C. Barbraud and H. Weimerskirch, "Emperor penguins and climate change," Nature, vol. 411, no. 6834, p. 183, 2001.

[7] S. M. Barber-Meyer, G. L. Kooyman, and P. J. Ponganis, "Trends in western Ross Sea emperor penguin chick abundances and their relationships to climate," Antarct. Sci., vol. 20, no. 1, pp. 3-11, 2008.

[8] J. Hansen, R. Ruedy, M. Sato, and K. Lo, "Global surface temperature change,” Rev. Geophys., vol. 48, no. 4, 2010.

[9] National Center for Environmental Information, "Climate at a glance :National Time Series." [Online]. Available: https://www.ncdc.noaa.gov/cag/. 